\title{
A Clinical Audit Study on Management of Childhood Epilepsy in Assiut University Hospital
}

\author{
FAROUK E. HASSANIEN, M.D.; GAMAL A. ASKAR, M.D. and SAMUEL M. FATHY, M.Sc. \\ The Department of Pediatrics, Faculty of Medicine, Assiut University Hospital, Assiut, Egypt
}

\begin{abstract}
Background: Seizures constitute the most common neurological problem in children and the majority of epilepsy cases has its onset in childhood.

Appropriate diagnosis and management of childhood epilepsy is essential to improve quality of life in these children.

Evidence-based clinical practice guidelines can improve the quality of life. There are many recommendations for diagnosis and management of different childhood seizures \& epilepsy.

Aim of Study: To evaluate management of epilepsy in Assuit University Children Hospital and compare it with the suggested guidelines of epilepsy management.

Patient and Methods: The study was conducted on patients attending to out-patient neurological clinic in Assuit University Children Hospital during the period from 1 st of January to $30^{\text {th }}$ of June 2017 .

Results: It was observed that the first line treatment (sodium valproate) was the most common drug used to control generalized epilepsy.

It was observed also that the first line treatment (carbamazepine) was the most commonly described in all cases of focal epilepsy.

Conclusion: Sodium valproate and carbamazebine are usually the most common drugs used to treatment of childhood epilepsy, it was observed that the majority of cases of epilepsy were controlled by monotherapy.
\end{abstract}

Key Words: Childhood epilepsy - Convulsions - Brain Antiepileptic drugs.

\section{Introduction}

SEIZURES constitute the most common neurological problem in children and the majority of epilepsy cases has its onset in childhood.

Correspondence to: Dr. Samuel Mores Fathy, E-Mail: samuelmores@yahoo.com
Appropriate diagnosis and management of childhood epilepsy is essential to improve quality of life in these children.

The clinical diagnosis of seizures is based on the history obtained from the patient and, most importantly, the observers. Physical examination helps in the diagnosis of specific epileptic syndromes that cause abnormal findings [1]

Evidence-based clinical practice guidelines can improve the quality of life. There are many recommendations for diagnosis and management of different childhood seizures \& epilepsy [2] .

EEG is recommended as a part of initial evaluation in all children presenting with seizures. Epileptiform abnormalities support a clinical diagnosis of seizure, help in diagnosis of specific syndromes \& predict seizure recurrence and help in choice of antiepileptic drugs. However, normal EEG does not rule out epilepsy [3]

MRI is superior to CT and it is preferred for initial screening procedure. Unlike CT scanning, MRI detects congenital malformations of the cortex, grey matter heterotopias and large proportion of arterio venous malformations. MRI is also an excellent screening test for detecting neoplasms even small sized [4].

The aim of treatment is complete seizure control without significant adverse effects and the choice of AEDs is based on the predominant seizure type.

\section{Abbreviations:}

AEDs : Antiepileptic Drugs.

A.U.C.H : Assiut University Children Hospital.

CNS : Central Nervous System.

CT : Computed Tomography.

C.S.F : Cerebrospinal Fluid. 
Predictors of seizure prognosis, including age of onset, gender, etiology, seizure type, EEG patterns, number of seizures prior to treatment and early response to treatment. People with multiple seizure types, in the childhood encephalopathies, appear to have a poorer prognosis [5]

The aim of this study is to: Assess how much the adopted protocol of management of Childhood epilepsy is implemented in Assiut University Children Hospital (A.U.C.H).

\section{Patients and Methods}

Research design: Clinical retrospective audit on management of childhood epilepsy at A.U.C.H from January 2017 to June 2017.

\section{Inclusion criteria:}

This clinical audit study included all children with:

- Simple focal seizures: The defining element of simple focal seizures is a seizure with preserved consciousness.

- Complex focal seizures: A complex partial seizure is defined as one in which there is some alteration or impairment of consciousness. Many patients with complex focal seizures have an aura warning them of their seizure [6]

- Primary and secondary generalized tonic-clonic seizures: Secondary generalized seizures often begin with an aura that evolves into a complex focal seizure and then into a generalized tonicclonic seizure. However, a complex focal seizure may evolve into a generalized tonic-clonic seizure without a preceding aura.

Clinically classifying a generalized tonic-clonic seizure as being secondarily generalized (focal onset) or primarily generalized is difficult on the basis of the history alone. In most cases, the association with prominent amnesia for the aura increases with the severity of a secondary generalized seizure [6]

- Myoclonic seizures: Myoclonic seizures consist of brief arrhythmic jerking motor movements that last less than 1 second and often cluster within a few minutes.

-Absence seizures: Typical absence seizures appear as brief staring spells. Patients have no warning or postictal phase, and if engaged in gross motor activity, such as walking, they may stop and stand motionless or they may continue to walk.

Atypical absence seizures, which occur in patients with symptomatic generalized epilepsies, are usually longer than typical absences and often have more gradual onset and resolution [6] .

- Atonic seizures: Atonic seizures are also called "drop attacks". These seizures occur in people with clinically significant neurologic abnormalities and consist of brief loss of postural tone, often resulting in falls and injuries (hence, some patients need helmets). The ictal EEG correlate is similar to EEG abnormalities observed in tonic seizures.

\section{Exclusion criteria:}

Children were excluded from this study if they were diagnosed as having:

- Typical febrile convulsions: Febrile convulsion is defined as age limited association between seizure and acute febrile illness in the absence of CNS infection, previous neonatal seizure, unprovoked seizures and acute symptomatic seizures.

- Atypical febrile convulsions: Atypical febrile convulsions has specific criteria (its duration more than 15 minutes, recurrent within $24 \mathrm{hrs}$ or focal convulsions.

- Convulsions due to CNS infections: Cerebro spinal fluid analysis is the most important method in diagnosis of CNS infections.

- Convulsions due to brain tumors: MRI is superior to $\mathrm{CT}$ and it is preferred for initial screening procedure.

- Neonates.

\section{Results}

This study was conducted on patients attending to Out-patient Neurological Clinic in Assuit University Children Hospital, the study included 100 patients diagnosed as having epilepsy. There were 59 males and 41 females. Trying to assess how much the adopted protocol of management of epilepsy was applied in Assiut University Children Hospital.

\section{Personal data of the studied groups:}

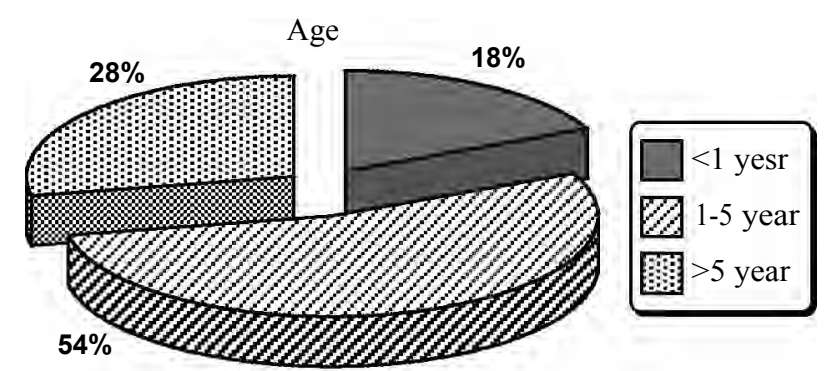

Fig. (1): Age distribution in the studied groups. 
Sex

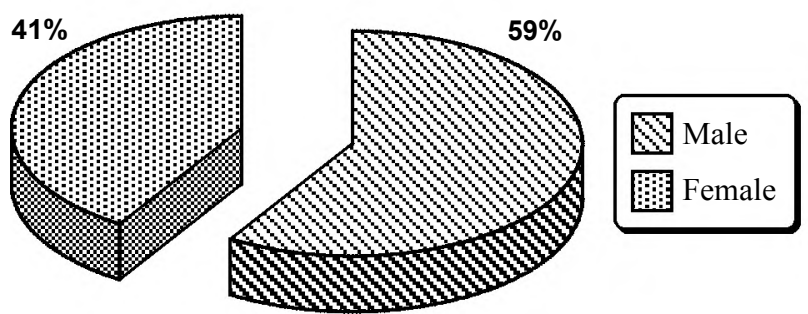

Fig. (2): Sex distribution in the studied groups.

Family history of epilepsy

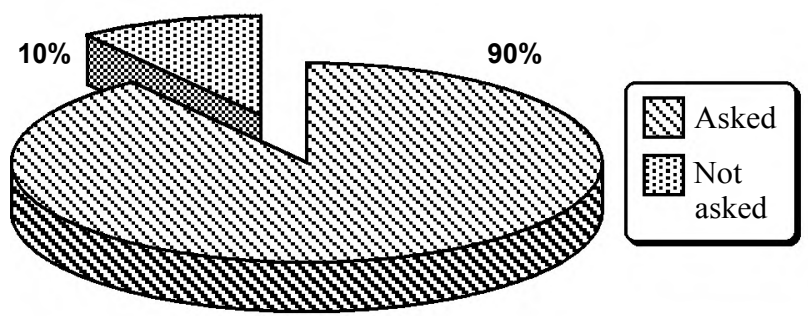

Fig. (3): Family history distribution in the studied groups.

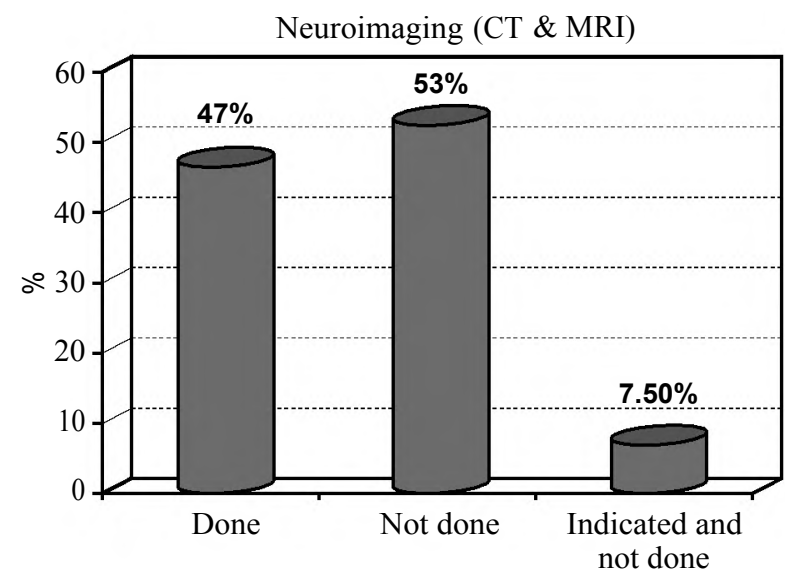

Fig. (4): Prevalence of neuroimaging (CT \& MRI) in the studied groups.

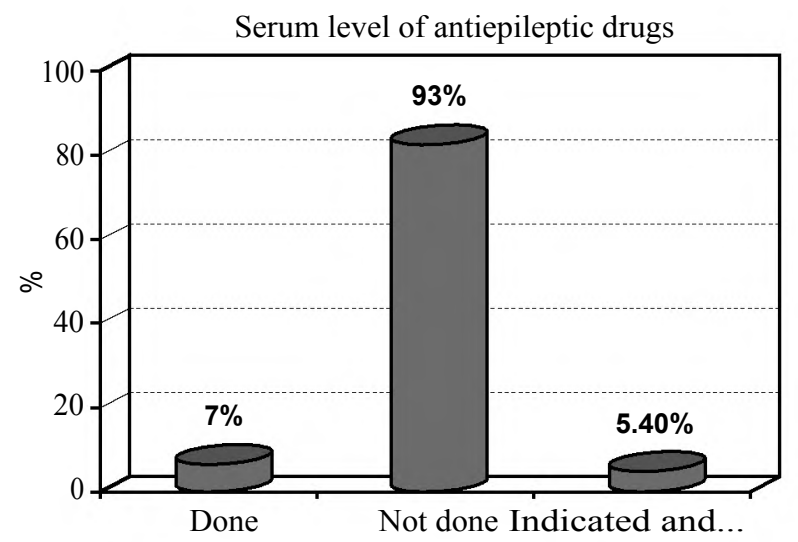

Fig. (5): Serum level of antiepileptic drugs in the studied groups.

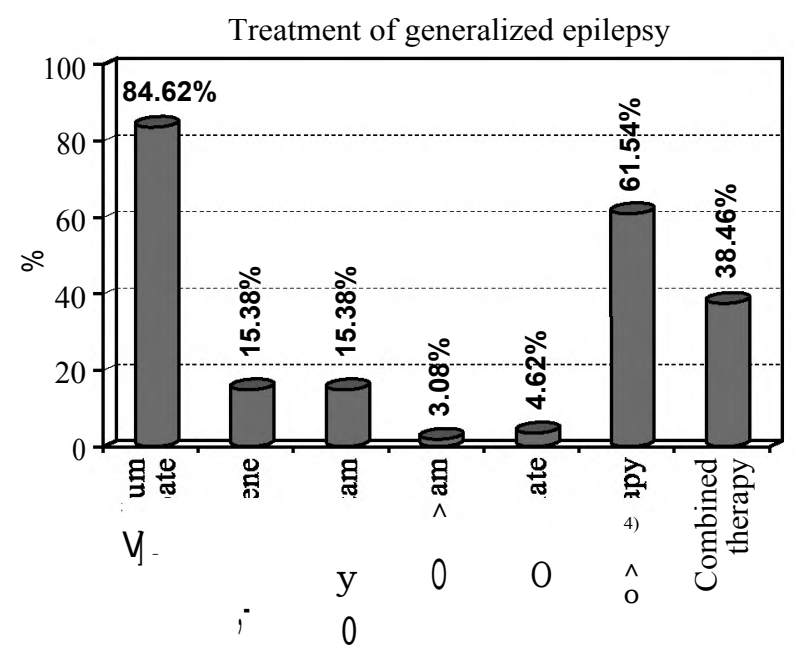

Fig. (6): Treatment of generalized epilepsy.

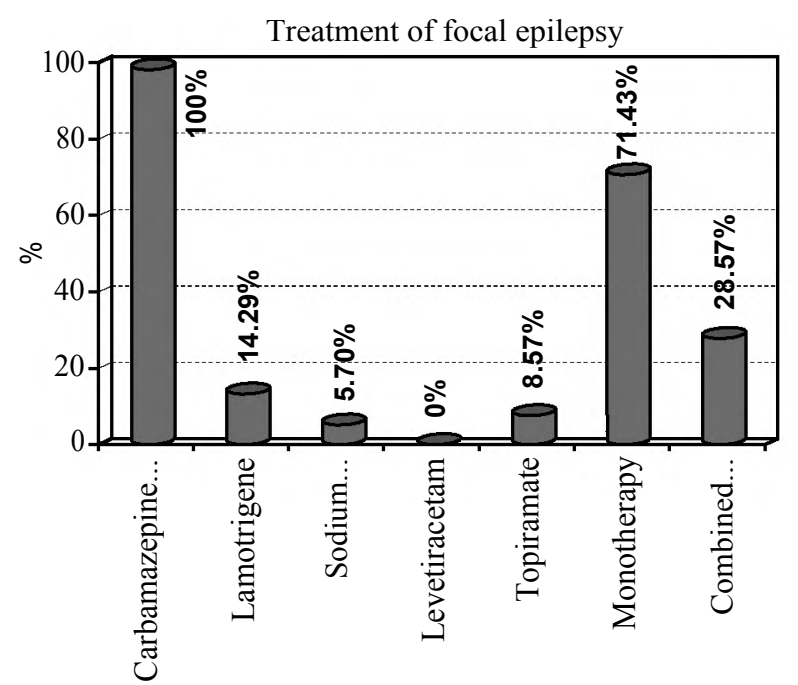

Fig. (7): Treatment of focal epilepsy.

Table (1): Clinical data of the studied groups.

\begin{tabular}{lll}
\hline & Number & Percentage \\
\hline Type of convulsion: & & \\
Generalized & 65 & 65 \\
Focal & 35 & 35 \\
Duration of convulsion: & & \\
$\quad$ Asked & 95 & 95 \\
$\quad$ Not asked & 5 & 5 \\
Change of level of consciousness: & & \\
Asked & 85 & 85 \\
Not asked & 15 & 15 \\
Vital signs: & & \\
Done & 95 & 95 \\
Not done & 5 & 5 \\
Head circumference: & & \\
Done & 95 & 95 \\
Not done & 5 & 5 \\
Abdominal examination: & & \\
Done & 70 & 70 \\
$\quad$ Not done & 30 & 30 \\
Full neurological examination: & & \\
$\quad$ Done & 85 & 85 \\
Not done & 15 & 15 \\
\hline
\end{tabular}


Table (2): Investigations of the studied groups.

\begin{tabular}{lll}
\hline & Number & Percentage \\
\hline CBC: & 79 & 79 \\
$\quad$ Done & 21 & 21 \\
Not done & & \\
EEG: & 100 & 100 \\
$\quad$ Done & 0 & 0 \\
$\quad$ Not done & & \\
Neuroimaging (CT \& MRI): & 47 & 47 \\
$\quad$ Done & 53 & 53 \\
$\quad$ Not done & 4 & 7.5 \\
Indicated and not done & & \\
Serum level of antiepileptic drugs: & 7 & 7 \\
$\quad$ Done & 93 & 93 \\
$\quad$ Not done & 5 & 5.4 \\
Indicated and not done & & \\
Liver function: & 9 & 9 \\
$\quad$ Done & 91 & 91 \\
$\quad$ Not done & 3 & 3.3 \\
Indicated and not done &
\end{tabular}

Table (3): Treatment of the studied groups.

\begin{tabular}{lcc}
\hline As regard generalized epilepsy & Number & Percentage \\
\hline $\begin{array}{l}\text { First line treatment: } \\
\quad \text { (Sodium Valproate) }\end{array}$ & 55 & 84.62 \\
$\begin{array}{l}\text { Second line treatment: } \\
\quad \text { Lamotrigene) }\end{array}$ & 10 & 15.38 \\
$\begin{array}{l}\text { Third line treatment: } \\
\quad \text { Levetiracetam ) }\end{array}$ & 10 & 15.38 \\
(Clonazepam) & 2 & 3.08 \\
$\quad$ (Topiramate) & 3 & 4.62 \\
Monotherapy & 40 & 61.54 \\
Combined therapy: & 25 & 38.46 \\
$\quad$ 1- Double therapy & 20 & 80 \\
2- Triple therapy & 5 & 20 \\
\hline
\end{tabular}

Table (3): (Continue).

\begin{tabular}{lll}
\hline As regard focal epilepsy & Number Percentage \\
\hline $\begin{array}{l}\text { First line treatment: } \\
\quad \text { (Carbamazepine or oxycarbamazepine) }\end{array}$ & 35 & 100 \\
$\quad$ Second line treatment: & 5 & 14.29 \\
$\quad$ (Lamotrigene) & & \\
$\quad$ Third line treatment: & 2 & 2.7 \\
$\quad$ (Sodium valproates) & 0 & 0 \\
$\quad$ (Levetiracetam) & 3 & 8.57 \\
$\quad$ (Topiramate) & 25 & 71.43 \\
Mono therapy & 10 & 28.57 \\
Combined therapy & & \\
Choice of the first antiepileptic drugs: & 95 & 95 \\
$\quad$ Proper & 5 & 5 \\
$\quad$ Improper & 5
\end{tabular}

Table (3): (Continue).

\begin{tabular}{llc}
\hline $\begin{array}{l}\text { Combination of } \\
\text { antiepileptic drugs }\end{array}$ & $\begin{array}{c}\text { Number } \\
\text { Percentage }\end{array}$ & $\begin{array}{c}\text { P4\% } \\
\text { Indicated }\end{array}$ \\
Not indicated & 32 & 91.4 \\
Proper combination & 3 & 8.57 \\
Improper combination & 33 & 94.2 \\
Compliance & 2 & 5.71 \\
Good compliance & 88 & 88 \\
Poor compliance: & 12 & 12 \\
$\quad$ 1- Due to defective education & 7 & \\
2- Personally & 5 & 41.67 \\
\hline
\end{tabular}

\section{Discussion}

In our study, it was observed that most of the studied cases aged from 1 to 5 years $54 \%, 28 \%$ aged more than 5 years and only $18 \%$ of cases aged less than 1 year.

Regarding type of convulsion, it was observed that most of the studied cases are presented with generalized type of convulsion (65\%) and only $35 \%$ of cases are presented with focal type.

The clinical diagnosis of seizures is based on the history obtained from the patient and, most importantly, the observers. Physical examination helps in the diagnosis of etiology of secondary epilepsy, such as dermatologic abnormalities (eg, neurocutaneous syndromes such as Sturge-Weber, tuberous sclerosis, and others).

In our study, the investigations usually considered include blood chemistries, complete blood count, Antiepileptic Drug (AED) levels, electroencephalography, and neuroimaging (Computed Tomography [CT] scan and Magnetic Resonance Imaging [MRI]. MRI is preferred because of its high resolution which can detect subtle abnormalities and also helpful in epilepsy pre surgical evaluation. The major part of evaluation can be performed after the child has been stabilized and the seizures have been completely or partially controlled.

In this study, it was observed that $\mathrm{CBC}$ was done for $79 \%$ of cases. It was also observed that EEG was done for all of the studied groups. Neuroimaging was done in $47 \%$ of cases and in $7.5 \%$ of cases was indicated but not done. Neuroimaging is not indicated in all cases of epilepsy but it is done in special circumstances like presence of abnormal neurologic examination, presence of dysmorphic features, intractable epilepsy, any 
convulsions starting in adolescence or planning for surgical treatment of epilepsy [7].

As regard serum level of antiepileptic drugs it was done in $7 \%$ of cases and not done in $93 \%$, it was indicated but not done in $5.4 \%$ of cases. Serum level of AEDs is not indicated in all cases of epilepsy but it is done in special circumstances like recurrence of fits after good control, at the time of status epilepticus, for patients with hepatic or renal diseases or on the presence of manifestations of drug toxicity [8]

As regard liver function it was done in $9 \%$ and not done in $91 \%$ of cases, it was indicated but not done in $3.3 \%$ of cases. It is usually done in the presence of hepatic affection (jaundice, hepatomegaly or ascites) or appearance of manifestations of drug toxicity.

The goal of treatment is complete seizure control without adverse effects from the use of antiepileptic drugs.

In this study, as regard treatment of cases of generalized epilepsy it was observed that $61.54 \%$ of cases were controlled by monotherapy and $38.4 \%$ of cases were controlled by combined therapy. It is observed that first line treatment (sodium valproate) was the most drug used to control generalized epilepsy cases with percentage of $84.62 \%$. And this agreement with [9].

As regard treatment of cases of focal epilepsy it was observed that $71.4 \%$ of cases were controlled by monotherapy and $28.5 \%$ of cases were controlled by combined therapy.

It was observed that first line treatment (carbamazepine) was described in all cases of focal epilepsy with a percentage of $100 \%$.

As regard choice of the first antiepileptic drug, in $95 \%$ of cases it was a proper choice.
As regard combination of antiepileptic drugs, it was indicated in $91.4 \%$ of case and in $8.5 \%$ of cases were not indicated and it was observed that in $94.2 \%$ of cases were proper combination and in $5.7 \%$ of cases were improper combination.

\section{References}

1- ELZAWAHRY H., DO C.S., LIN K. and BENBADIS S.R.: The diagnostic utility of the epilepsy. Epilepsy Behav., Jul., 18 (3): 306-7, 2010.

2- GAILLARD W.D., CHIRON C., CROSS J.H., HARVEY A.S., KUZNIECKY R., HERTZ-PANNIER L., et al.: Guidelines for treatment of generalized seizures. Epilepsia, Sep., 50 (9): 2147-53, 2013.

3- PAL D.K.: Epilepsy control in the 21 st century: Leave no child behind. Epilepsia, 44: 273-5, 2010.

4- BERGEN D., BLECK T., RAMSEY R., et al.: Magnetic resonance imaging as a sensitive and specific predictor tool in epilepsy. Epilepsia, 30: 318-21. (Level III evidence), 2014.

5- MATTSON R.H., CRAMER J.A. and COLLINS J.F.: Prognosis for total control of complex partial and secondarily generalized tonic clonic seizures. Department of Veterans Affairs Epilepsy Cooperative Studies No. 118 and No. 264 Group. Neurology, Jul., 47 (1): 68-76, 1996.

6- RUDZINSKI L.A. and SHIH J.J.: The Classification of Seizures and Epilepsy Syndromes. Continuum: Lifelong Learning in Neurology, Jun., 16 (3): 15-35, 2010.

7- BERG A.T., MATHERN G.W., BRONEN R.A., FULBRIGHT R.K., DiMARIO F., TESTA F.M., et al.: Frequency, candidates and surgical treatment of structural abnormalities in childhood epilepsy. Brain, Oct., 132: 2785-97, 2009.

8- ENGEL J. Jr.: Report of the ILAE classification core group. Epilepsia, Sep., 47 (9): 1558-68, 2006.

9- TAVERNA S., MANTEGAZZA M., FRANCESCHETTI S. and AVANZINI G.: Valproate selectively reduces the persistent fraction of $\mathrm{Na}+$ current in neocortical neurons. Epilepsy Res., Sep. 32 (1-2): 304-8, 2011. 


\section{دراسة إكلينيكية تدقيقية لعلاج مرض الصرع فى الآطفال

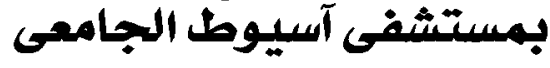

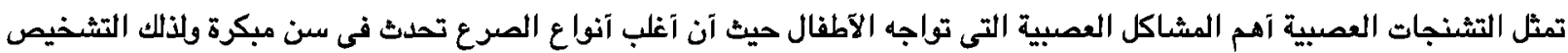

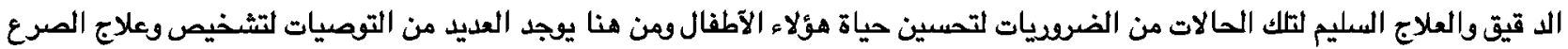

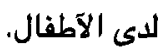

الهدف من الرسالة: محاولة وضع نظام محدد لعلاج مرض الصرع ومقارنته مع النظام المتبع فى العالم لعلاج مثل تلك الحالات. تصميم البحث: يتم تسجيل جميع حالات الصرع المترددة على عيادة الآمراض العصبية بمستشفى الآطفال جامعة آسيوط ومقارنة العلاج

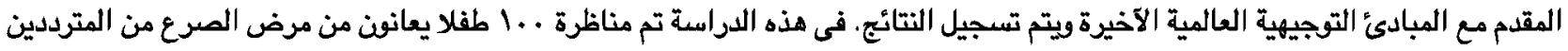

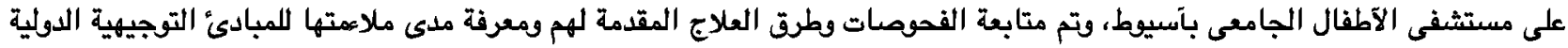

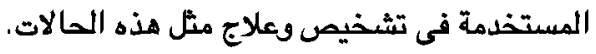

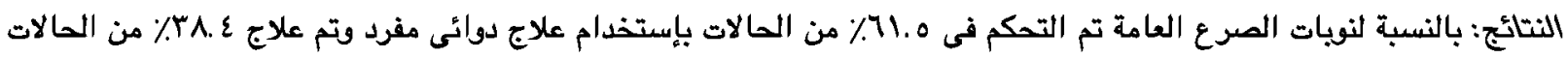
بإستخدام آكثر من نوع من الآدوية.

كان عقار فالبروات الصوديوم من آكثر الآدوية المستخدمة فى علاج نوبات الصرع العامة وذلك بنسبة ؟.^ع٪ من الحالات.

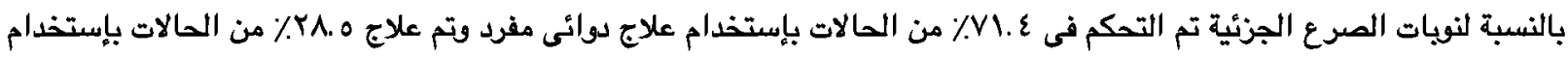
آكثر من نوع من الآدوية. كان عقار (الكاربامازيبين) من آكثر الآدوية المستخدمة فى علاج نويات الصرع الجزئية وذلك بنسبة . . 1٪ من الحالات. التوصيات:

ا- ينصح بآخذ تاريخ مرضى كامل لكل مرضى الصرع المترددين على عيادة العصبية.

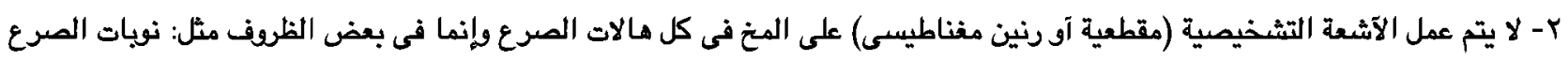

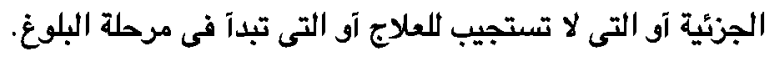

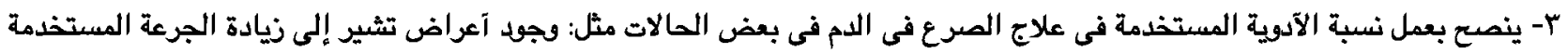

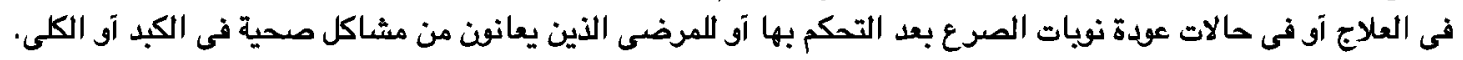

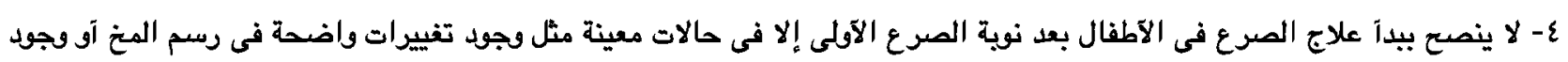

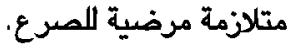
ه- ينصع بعمل زيارات للمتابعة للمرضى في بداية المرض كل شهر آوشهرين حتى يتم التحكم في نوبات الصرع ثم بعد ذلك كل من (ب-7) أشهر حسب حالة كل مريض على حدة. 